\title{
State of Religious Beliefs and Observance of Five Pillars of Islam Among the Muslim School Heads of the Department of Education (DepEd)
}

\author{
Ali K. Dilangalen \\ Cotabato Foundation College of Science and \\ Technology (CFCST), Philippines \\ akdilangalen@yahoo.com
}

\author{
Emraida K. Dilangalen \\ Cotabato Foundation College of Science and \\ Technology (CFCST), Philippines \\ akdilangalen@yahoo.com
}

\begin{abstract}
Generally, the study was conducted to determine the level of knowledge of internalizing the Muslim school heads on the six articles of faith and the state of religious observance on the five pillars of Islam. It explored the influence of the socio-demographic and economic profiles and selected factors on the six articles of faith and pillars of Islam and the significant relationship between articles of faith and five pillars of Islam. Data revealed that certain factors affect religious observance of Muslim school heads. They had a moderately strong knowledge in internalizing the six articles of faith in terms of belief in Allah's Angel, Books, and Prophets; but weak in faith of Belief in Allah, Day of Judgment, and Allah's Predestination. They have internalized Shahaadah; oftentimes observed Shalaah, Zakat, and Sawm; but sometimes observed Hajj. The respondents were aware of their roles in observing the articles of faith and pillars of Islam but they did not faithfully perform it for some reason. This study recommends that Muslim school heads should know and perform their religious obligation because the only reason why Allah created Man and Jinn is to Worship Him.
\end{abstract}

Keywords: religious beliefs, pillars of Islam, articles of Islamic faith, school heads, department of education

\section{INTRODUCTION}

Islam is the fastest-growing religion in the world. Based on the growth of the Muslim populations of the world, Lipka and Hackett (2015) estimated that in the next half-century or so, Christianity's long reign as the world's largest religion may come to an end. Such a claim was recently released from their reports on population growth projections for religious groups published by Pew Research Center [1], [2]. In Europe, Islam is the secondlargest religious belief after Christianity.

During the 2010 Pew Forum, the total number of Muslims in Europe was estimated to 44 million which is $6 \%$ of the total population including the 19 million $(3.8 \%$ of the population) in the European Union [3], [4]. These figures were obtained primarily due to the results of Muslim immigration from England and other parts of the globe [5], [6], [7].

On the other side of the globe being dominated Muslim populace, no doubt that Islam is currently the largest religion in Asia (25\%) followed by Hinduism. In 2010, the total number of Muslims in Asia was about 1.1 billion. It was recorded further than $62 \%$ of the world's Muslims live in Asia. As such, Asia is considered as the home of the largest Muslim population.

The 2017 Census of Population in the Philippines has recorded a total of 105,718,532. The Philippines is the only country in Asia that was dominated by Roman Catholic and by the number of Islam believers. The majority of these Islam believers are found in the Island of Mindanao and the numbers are steadily growing fast.

As the number of Muslims increased in this part of the country, the number of professionals who are government employees is increasing. Specifically, from the Department of Education (DepED) particularly in the Cotabato Division, the numbers of Muslim school administrators are noted. These school administrators are always bringing the name Muslims with proud everywhere they are [8], [9].

A great challenge of being a Muslim is the level of know-how on the Six (6) Articles of Faith and the observance of the Five (5) Pillars of Islam. The articles of faith are manifested in the belief while the pillars must be justified in the deeds. Indeed, this work on the knowledge level of the belief and status of doing those pillars among the DepEd Muslim school administrators are worthy to be investigated.

\section{A. Statement of the Problem}

Islam is anchored from beliefs and actions. The six articles of faith are related to the state of beliefs. On the other side, the five pillars are striking the deeds. Hence, this study shall investigate in general the state of religious beliefs and observance of five pillars of Islam among the Muslim school administrators from the Department of Education. In professing Islam, one must believe in what he/she does and must do what he/she believes too.

The following specific inquiries are being drawn to provide details of investigations that shall help answer the general research problem: (1) what are the socioeconomic profiles of the DepEd Muslim school heads? (2) What are the different factors that may affect the school administrators' beliefs and observance of the pillars of Islam? (3) what is the knowledge level of the DepEd Muslim school heads on the six articles of faith? (4) what is the state of observance of the DepEd Muslim school administrators on the five (5) pillars of Islam? (5) do the socio-demographic profiles of the DepEd Muslim school administrators affect their knowledge level on the six articles of faith? (6) do socio-demographic profiles of the DepEd Muslim school administrators affect their knowledge levels on the state of observance on the five pillars of Islam? (7) do selected factors like economic, environmental, and social significantly affect the knowledge level on the six articles of faith? (8) do selected factors like economic, environmental, and social significantly affect the knowledge level on the five pillars of Islam among the DepEd Muslim school administrators? (9) is there any significant relationship between the knowledge level on the six articles of faith and the state of observance on the five pillars of Islam? 


\section{B. Significance of the Study}

The result of they may serve as the basis for strengthening, improving, and enhancing the level of knowledge on the six articles of faith and state of religious observance among Muslim school administrators [10]. Through this humble work, as manifested by the results of the target respondents, were used to assess and evaluate the degree of their being true believers of Islam.

The result may serve as an eye-opener to every Islam believer that observance of the five pillars of Islam is a must and personal commitment. Hence, the result of this study is of great importance much so to the Muslim administrators. They may be guided to practice their religious obligations and develop in themselves the value and importance of religious observance to be a good Muslim administrator who will impart Islamic ideologies to their teachers, pupils, to the community and the country as a whole.

It is expected that Islam believers are very committed to their work, not corrupt, and with good human relationships with others. To those who are concerned with the fulfillment of their religious observance, the upliftment and development of the believers of Islam, the result of this study can be of great help [11].

\section{Scope and Delimitation of the Study}

This study was focused only on the level of knowledge and state of religious observance of the Muslim school heads of the Cotabato Division on the six articles of faith and the five pillars of Islam for the school year $2017-2018$. The subjects of the research were the Muslim school heads. The study was also focused on the influence of the selected problems on the level of knowledge of the Muslim school heads on the six articles of faith and the state of observance on the five pillars of Islam. The significant degree of relationship between the level of knowledge on the six articles of faith and state of religious observance on the five pillars of Islam were considered.

\section{Operational Definition of Terms}

For a better understanding of this study, the following terms are operationally defined:

a. Asatids: It is the plural form of the Arabic word Ustadz which means professor. It is commonly used for Arabic teachers.

b. Deen: It is an Arabic word used for religious description on the way of life, rule of conduct, ideology, and religion of peace.

c. Fasting (Sawm): It is a religious obligation of Islam to abstain entirely from or limit of food;

d. Hajj: It is the fifth pillar of Islam which is prescribed for those Muslims who can afford the trip financially to go to Mecca once in a lifetime for a Pilgrimage to Mecca that is undertaken by Muslims during the month of Zulhijah.

e. Islam: It is an Arabic word for Muslim religion which means peace, surrender, complete submission, and obedience to the will of Allah.

f. Shalaah: It is the second pillar of Islam which is an Arabic word for obligatory prayer and must be performed five times a day to worship the creator by one who wants to establish closeness to Him.

g. Shahaadah: It is the first pillar of Islam. It is an Arabic word for: "Ash-hadu Allah ilaahaillallah, wa ash-haduanna Mohammador Rasuulullah. The literal meaning is that I bear witness that there is no God but Allah and Mohammad (p.b.u.h) is His messenger.

h. Zakaat: It is an Arabic word. It is translated in the English language as a poor rate. The payment of Zakaat is one of the obligatory acts imposed by Islam to all capable Muslims whose earning reached its nisaab. Muslim earnings must be cleansed to make it halal or pure.

i. Environmental Factors: These are factors that can affect the Islamic activities referred to in the study such as residence, religious facilities in the school, peers, attendance in social occasions, type of schools, and type of communities.

j. Islamic Orientation: It refers to the Islamic activities of the family that conform to the teaching of Islam.

k. Lailatul Qad'r: It is an Arabic word for the night of majesty. It refers to the night on which the revelation of the Holy Qur'an began. It is a night of great wonders and blessings which Allah described as "better than one thousand months". This means that the reward of devotion during this night is better than the reward to be expected for devotion in one thousand months.

1. Magna Carta for Public School Teachers: Republic Act Number 4670. An act is known as Magna Carta for public school teachers and applies to all publicschool teachers and those in the professional staff of state colleges and universities. This act aim to promote and improve the social-economic status of public school teachers, their living and working conditions, their employment and career prospects in order that they may compare favorably with existing opportunities in other walks of life, attract and retain in the teaching profession more people with the body, not to utter anything that hurts other people, not to do anything that is against the will of Allah.

m. Socio-economic Profiles: It refers to the variables categorized as age, civil status, sex, educational attainment, length of service, and tribe.

\section{METHODS}

Research design, this study employed a combination of descriptive surveys and descriptive correlation methods. Such a design is appropriate for describing the profile of respondents. The perceptions of the respondents on the factors that affect their religious practices are best described through the use of this design. This study was conducted in the Districts of Cotabato Division in Region XII wherein Muslim principals, headteachers, or teachers - in charge are found.

The areas covered by the study were the elementary districts identified as having majority Muslim heads. A complete enumeration of all Muslim school heads was done to get the number of respondents in the selected Elementary Schools of Cotabato Division in Region XII. Principals, headteachers, and teachers - in charge were completely included as respondents of the study. Respondents of the study, the subjects of the study 
were the Muslim principals, headteachers, and teachers in charge of an elementary school in the 17 municipalities of North Cotabato. Table 1 shows the distribution of respondents.

Table 1

School with Muslim Heads in the Different Municipalities of Cotabato Division

\begin{tabular}{|c|l|c|}
\hline No. & \multicolumn{1}{|c|}{ Municipality } & $\begin{array}{c}\text { Muslim } \\
\text { Heads }\end{array}$ \\
\hline 1. & Alamada & 2 \\
\hline 2. & Aleosan & 2 \\
\hline 3. & Antipas & 0 \\
\hline 4. & Arakan & 0 \\
\hline 5. & Banisilan & 5 \\
\hline 6. & Carmen & 7 \\
\hline 7. & Kabacan & 15 \\
\hline 8. & Libungan & 0 \\
\hline 9. & Magpet & 0 \\
\hline 10. & Makilala & 0 \\
\hline 11. & Matalam & 6 \\
\hline 12. & Midsayap & 18 \\
\hline 13. & Mlang & 0 \\
\hline 14. & Pigkawayan & 4 \\
\hline 15. & Pikit & 3 \\
\hline 16. & President Roxas & 0 \\
\hline 17. & Tulunan & $\mathbf{1 1 8}$ \\
\hline \multicolumn{2}{|c|}{ Total } & \\
\hline
\end{tabular}

Research instrument, to get valid and reliable data for this research, a questionnaire of four (4) parts was made as to the main research tool to gather necessary data. This will be patterned from the study of Hashim (2005). A certification from him was secured to use his instrument before the conduct of the study. Other parts of the instrument were secured from the Holy Qur'an and Sunnah of the Prophet.

Set A was used to elicit the socio-economic profile of the respondents. Set B was used to gather information on the different factors that affect the religious performance of the respondents. This part was rated using the following scales: 1 = strongly disagree; 2 = disagree; $3=$ moderately agrees; $4=$ agree; and $5=$ strongly agree . Set $\mathrm{C}$ was used to get the level of knowledge of the respondents in internalizing the six articles of faith. This part was rated based on the scores of the respondents.

Scores was rated using the following scales: $1=$ least internalized; 2 = less internalized; $3=$ moderately internalized; 4 = internalized; and $5=$ highly internalized. Set D was used to elicit the religious observance of the Muslim school heads in five pillars of Islam. The following scales were used to rate: 1 = very weak; 2 = weak; $3=$ moderately strong; $4=$ strong; and $5=$ very strong.

Data gathering procedure, after the proposed study was defended and approved by the dissertation examining and advisory panels, the researcher secured a communication letter noted by the adviser addressed to the Schools Division Superintendent for approval to conduct the study. Upon approval of the communication, the researcher secured the list of the Districts where Muslim heads are located. After having the list, the approved communication was presented to the involved district supervisors then the distribution of the instruments was done.

Method of data analysis, the socio-economic information was gathered, tallied, and coded. It was analyzed using frequency and percentage. Responses on the problems affecting the religious beliefs and observance of the respondents were analyzed using weighted mean. The level of knowledge of the respondents in internalizing the six articles of faith were analyzed based on their scores while the state of religious observance among the respondents was analyzed using weighted mean. Hypotheses of the study were tested using correlation and multiple regression techniques.

\section{RESULTS AND DISCUSSION}

This study was conducted to ascertain the state of religious beliefs and observance of the five pillars of Islam of the Muslim administrators of the Cotabato Division. Specifically, it sought to describe the socioeconomic profiles of the DepEd Muslim school heads; identify the different problems that may affect the school administrators' beliefs and observance of the pillars of Islam; describe the knowledge level of the DepEd Muslim school heads on the six articles of faith; and determine the state of observance of the DepEd Muslim school administrators on the five pillars of Islam.

It further determined the described the influence of the socio-demographic profiles of the DepEd Muslim school administrators on the knowledge level on the articles of faith; the influence of the socio-demographic profiles of the DepEd Muslim school administrators on their knowledge levels on the state of observance on the five pillars of Islam; the influence of the factors on economic, environmental, and social on the the knowledge level on the six articles of faith; the influence of the factors like economic, environmental, and social on the knowledge level on the five pillars of Islam among the DepEd Muslim school administrators; and the significant relationship between the knowledge level on the six articles of faith and the state of observance on the five pillars of Islam [12], [13].

Four sets of measuring tools were used in gathering the necessary data. Part I consists of items that gathered information on the socio-demographic and economic profiles of the Muslim school heads; Part II elicited the different factors that affect religious observance of the Muslim school heads; Part III for the six articles of faith; and Part IV was for the five pillars of Islam. The survey instrument was adopted, modified, and validated with Cronbach's reliability test that gained an alpha value of 0.844 . Pilot testing was conducted for $20 \%$ of the target respondents. Complete enumeration was used to determine the 118 Muslim school heads in the different districts of the Cotabato Division as respondents of the study.

Results revealed that out of 118 Muslim school heads, 36 were under the age bracket of $43-47$ years old, female, married, a baccalaureate degree in English education, no formal education in Arabic education, and $16-20$ years in service. On the selected factors that affect religious observance of Muslim school heads, findings revealed that they disagree to have extra sidelines like farming, business, and other sources of income.

Muslim school heads moderately agreed that environment like a school assignment and residence/community where they live affect their religious observance; social factors also moderately affect the 
religious observance of the Muslim school heads [14], [15], [16].

Finding implies that selected factors like other sources of income, environment, and social factors do not affect the extent of religious performance of the Muslim school heads. Performance in religious practices of anyone does not affect by any factors. It depends on the sincerity and fair of anyone to His Creators. Some Muslim school heads are aware of their obligation to His Creator but lack in terms of performance, but others are very limited knowledge about their religion [17], [18].

As to the level knowledge level on internalizing the articles of faith, the result revealed that Muslim school head is moderately strong knowledge in internalizing their Belief in Allah's Angel, Books, and Prophets; and they were weak in faith of Belief in Allah, Day of Judgment, and Allah's Predestination. The finding of the study is a manifestation that Muslim school heads have limited knowledge about the six articles of faith [19], [20], [21].

As to observance of the five pillars of Islam, the findings revealed that Muslim school heads internalized Shahaadah; oftentimes observed Shalaah, Zakaat, and Sawm; but sometimes observed Hajj. It means that Muslim school heads observed all the pillars of Islam but lack of actual performance on it [22], [23], [24]. As to the influence of the socio-demographic and economic profiles on the articles of faith, the result revealed that Muslim school heads' profiles significantly influenced their level of knowledge on internalizing the articles of faith where age, sex, and articles of faith found to be the best indicators.

Result revealed also that selected factors significantly influenced the knowledge level of the Muslim school head-on internalizing the articles of faith where the environment as the best predictor. Sociodemographic and economic profiles of the Muslim school heads significantly influenced their observance in five pillars of Islam particularly on Shalaah with civil status as a predictor; Zakat with age as a predictor; and Hajj with monthly income and Arabic education as predictors. It shows that Muslim school heads profiles do not significantly influence their observance in Shahaadah and Sawm. Selected factors like other sources of income, environment, and social factors significantly influenced the level of observance on the five pillars of Islam particularly in Shahaadah with economic factors as predictors; Shalaah with social factors as predictors; Zakaat with the environment as a predictor; and Sawm with economic factor as a predictor. However, Hajj was not influenced by the selected factors.

\section{CONCLUSION}

It is concluded based on the findings of the study that Muslim school heads of the Cotabato Division were on their middle age, male, married, baccalaureate degree in English, no formal education in Arabic, and $16-20$ years in service as administrator. Muslim school heads disagree that they engage another work that earns income aside from their teaching profession; moderately agree that environment and social factors affect religious observance. It further concluded that Muslim school heads are moderately strong in internalizing the articles of faith like Belief in Allah's Angels, Books, and Prophet
[25], [26], [27]. However, they were very weak on their knowledge in internalizing the articles of faith like Belief in Allah, Day of Judgment, and Allah's Predestination. As to the state of religious observance on the five pillars of Islam, Muslim school heads internalized the Shahaadah; oftentimes observed Shalaah, Zakaat, and Sawm.

However, they sometimes observed Hajj. It means that Muslim school heads observed and aware about the pillars of Islam but the only problem is knowledge and frequent practice of it [28]. It can also be concluded that the older the male Muslim school heads, and the longer they had been in the service as school heads, the higher is their knowledge about internalization of the six articles of faith.

It could further be concluded that environment like school assignment and residence / community where Muslim school heads assign significantly contributed to their knowledge level on internalizing the six articles of faith [29]. Female Muslim school heads observe religiously the pillars of Islam like Shalaah; the older is the Muslim school heads, the more they give Zakat; and the longer is the service as school heads and the bigger is the monthly income, the more chances of observing the pillars of Islam in terms of Hajj [30].

However, profiles of the Muslim school heads do not affect their religious observance on the pillars of Islam particularly in Shahaadah and Sawm. The selected factors significantly influence the pillars of Islam like Shahaadah with economic factors as predictor; Shalaah with social factors as predictor; Zakat with environment as predictor; and Sawm with economic factors as predictor. However, selected factors do not affect pillars of Islam like Hajj; and (7) It is also concluded that significant degree of the relationship was noted between Shahaadah and Belief in Allah and Allah's Angels; Shalaah and Belief in Angels; Sawm and Belief in Angels; and Hajj and Belief in Allah.

\section{RECOMMENDATION}

Based on the findings of the study, the recommendation was anchored on the verse in the Holy Quran. Allah says in Chapter 51 and verse 56: I did not create the jinn and man but to worship me. Being workers in the government is not a justification for not performing the religious obligation to His Creator.

The agencies of the government do not forbid anyone to practice their religion anywhere in the office or the classroom. Instead, the Department of Education promotes culture sensitivity. Offices/classrooms are a good venue to perform Shalaah. It is recommended that Muslims shall perform and practice the eleven fundamentals of Islam, because man is created by the Great Creator to worship him.

\section{REFERENCES}

[1] Abdalati, H. 1975. Islam in Focus. American Trust Publications. 10900 W. Washington St. Indianapolis, USA.

[2] Abu'1 - Fadal, M. 1992. Sayings of Mohammad. Da'wah Academy. International Islamic University. Islamabad, Pakistan.

[3] Alavi, K. 1990. Role of the Mosque in the Muslim Community. Da'wah Academy. IIU, Islamad, Pakistan. 
[4] Al - Hilali T. Khan, M. 1994. Interpration of the Meanings of the Noble Holy. Qur'an. English Translation.

[5] Azzam, S. 1997. Islam: It Meaning and Messages. A. H. Publisher. 22 Al Fazzal Market Urdu Bazar. Lahori, Pakistan.

[6] Bernad, B. 1989. Sociologu from Concept to Practice. Mc Grew Hill Inc. Boston, USA.

[11] Majul, C. 1980. Islam and Development. OCIA Publications. Metro Manila Philippines.

[12] Panopio, I., MacDonald, F., Raymundo, A. 1995 Sociology Focus on Philippines. Ken Incorporated, Quezon City, Philippines.

[13] Ul - Haq, Z. 1994. Economic teaching of the Holy Prophet. Da'wah Highlight. IIU, Islamad, Pakistan.

[14] Zahid, B. 1997. Forty Hadith. First Edition. Progressive Books. Urdo Bazar, Lahpre, Pakistan.

[15] Abas, E. 1982. Zakaat and Sharing. Al Nahda, Kuala Lumpur, Malaysia.

[16] Dalamban, N. 2007. The Involement of Bangsamoro Women in Implementing Rural Development Program. Dissertation USM, Kabacan, Cotabato.

[17] Dilangalen, A. 2007. Sustainability of Madrasah Educational Sytem in the Province of Cotabato and Maguindanao. Dissertation USM, Kabacan, Cotabato.

[18] Hashim, E. 2005. Factors Affecting the Level of Teaching Competencies of Arabic Teachers in the Second Congressional District, Division of Maguindanao. Masters Thesis USM, Kabacan, Cotabato.

[19] Kusain, H. 1996. The Demographic Profile of Residence of Purok Islam, General Santos City. Undergraduate Thesis, MSU, General Santos City.

[20] Murray, S. 2002. Development of Training Modules on Environmental Protection. Dissertation. USM Kabacan, Cotabato.
[7] Esmael, A. 1982. Zakaat and Wealth Sharing. Al Nahda, Kuala Lumpur, Malaysia.

[8] Espiritu, S. 1960. Sociology and Social Living. JMC Press, Incorporated, Philippines.

[9] Handle and Lauer. 1981. Social Psychology: The Theory and Application. Symbolic Interaction, USA.

[10] Ebrahim, E. 1987. Forty Hadith. Progressive Books. 40 Urdu Bazar, Lahore, Malaysia.

[21] Musa, S. 2008. Formative Assessment of the Madrasah Curriculum in Pikit District, S.Y. 2007 - 2008. Master's Thesis. USM Kabacan, Cotabato.

[22] Alavi, K. 2002. Fasting in Prophetic Traditions. Da'wah Academy. International Islamic University, Islamabad, Pakistan.

[23] Abdul - Aziz bin Abdullah bin Baz. 2003. Haij, Umrah and Ziyarah in the Light the Qur'an and Sunnah. King Fahad National Library. Riyadh, Saudi Arabia.

[24] Al Qassim. 1999. Islam: The Essentials. King Fahad National Library. Islamic Foundation. England.

[25] Lapus, J. 2008. Department of Education Personnel Handbook. Manila, Philippines.

[26] Hamidullah, M. 2005. Daily Life of a Muslim. Da'wah Academy. International Islamic University, Islamabad, Pakistan.

[27] Mawdudi, S. 2002. Updating Islam, Faulting Line. The Islamic Foundation, U.K Institute of Policy Studies, Islamabad, Pakistan.

[28] Murad, M. 1994. Islam in Brief. Riyadh, Kingdom of Saudi Arabia.

[29] Quseshi, M. 2004. Islam: The Most Humane Religion. Da'wah Academy. IIU Islamabad, Pakistan.

[30] Quseshi, M. 2004. Islam Religion: Islam View. Da'wah Academy. IIU Islamabad, Pakistan. 